\title{
Bad Faith an Exploration of the Work of Sartre
}

\author{
*Paria Tirsahar \\ Gothenburg University, Sweden
}

Submission: July 15, 2017; Published: August 02, 2017

*Corresponding author: Paria Tirsahar, Gothenburg University, Sweden; Tel: 2070934340; Email: paria.kiarash@yahoo.com

\section{Introduction}

Jean-Paul Sartre is possibly the most recognized philosopher of the twentieth century. "His diligent pursuit of philosophical view, scholar creativity, ingenuity and resourcefulness and, in the second other half of his life, he was politically very active which gave him an international reputation and recognition. He is generally known as the Father of Existentialist Philosophy, "whose work set the tone for intellectual life in the decade immediately following the Second World War" (Stanford Encyclopedia of Philosophy, 2004). Sartre's philosophical and rational reflections can be structured into five categories, namely psychology, ontology, ethics, political responsibility, and the relationship between the fine arts and philosophy, specifically concerning literature.

Bad faith is the official phrase and was used by Kierkegaard for the first time, and as Sartre [1] says." It is a paradoxical confusing perplexing and therefore ultimately a schizophrenic attempt at self-deception, although the fact it may even be the normal aspect of life for many people." I choose to discuss Sartre's bad faith (mauvaise foi) as I believe in human authenticity based on freedom and responsibility and that one can live in good faith and am conscious of the nothingness of our being. That is we all have to deal with our anxiety and loneliness when we face challenges happen. The substructure of Sartrean autonomy is existential. Judaken [2] says:"that is, we are free because we are not a self (an in-itself) but a presence-to-self (the transcendence or "nihilation" of our self). This implies that to ourselves we are "other". That is, whatever we are or however others may regard us, we are in the position of being neither as well as in the position of being able to assume a perspective about how they view us.

The above means the inner gap shows not only the non-selfidentity for-itself and the temporality of it but it shapes what Sartre [1] calls "freedom as the definition of man." But then the level of this freedom is a match and is comparable to the level of respon $\neg$ sibility we have. That is, we are responsible for "our" world because the world is the realm of meaning in which we act, and we also are responsible for everything in it, and we have the freedom to choose what to make of it based on our values and standards. Sartre's theory of authenticity, which has been regarded as the only existentialist value, has been criticized for being just a way of living rather than having any content. But its base is phenomenological - and it refers to the ambiguity we may face when we become the one that we are not and therefore not what we are. Being authentic basically means being true to one's own existence and personality and attempting to come to terms with the pressure from our internal conflicts as well as challenges from the external world.

For Anderson [3] the claim "that's just the way I am" would create a form of self-deception or bad faith as would all forms of determinism, as both instances involve lying to oneself about the ontological fact of one's non-self-coincidental and the flight from coincidental responsibility for "choosing' to remain that way". That is, we may pretend to ourselves that we do not have any choice, but we cannot pretend to ourselves that we are not ourselves, that we are not a mindful and responsive being regardless of our social status, standard systems or practical involvements.

\section{Bad Faith Versus alternative Lying}

Bad faith has often been classified as deception. We usually denigrate people who are in bad faith, but there is a difference between lying to ourselves and lying in the general sense. Lying however, does not have any impact on awareness itself; it is only at the transcendental level that the liar is lying to others for at the same time he is completely aware of the truth which he is hiding. This means that we cannot be said to be lying when we are unaware of the truth; we do not lie when we make mistakes because we ourselves are the victim of deception; that is, we do not lie when we are mistaken ourselves. 
As Aronson [4] says, "the perfect description of the liar would be a cynical consciousness, affirming truth within him, denying it in his words, and denying that negation as such. Now this doubly negative attitude rests on the transcendent; the fact expressed is transcendent since it does not exist, and the original negation rests on a truth, that is, on a particular specific type of transcendence". The liar is denying the truth but denies that he denies the truth, and this all happens in transcendence for in reality it does not exist. And the initial denial is relying on a truth.

The point is that lying is depending on words, that is, that the liar is not trying to hide the truth from him and is fully aware of his own intentions. His intention is to cheat on others while his own consciousness is kept intact because he is not trying to mask the truth to from himself. Sartre [1] has described the difference between the lie to self and the lie to other as "the lie to others does not put into the play the inner structure of present consciousness; all the negations which constitute it bear on objects which by this fact are removed from consciousness".

To me perhaps the lie is what Heidegger defines as the Mitsein, that is, in a lie I exist for the Other, and the Other exist for me, and as a liar I have to make sure that the plan of lying is completely clear. As a liar I have to be clear and understand both the lie perfectly as well as the truth which I am changing. The most important reason for lying is to persuade the other to take the lie for truth. But this is not the case with bad faith because lying in bad faith is actually lying to oneself in a way that is masking an annoying truth or treating an unpleasant truth as a lie.

Bad faith then has same format and design as deception which in Sartre [1] words means that whenever one is in bad faith, just as in lying, I lie, but to myself only and not to any other person. In that case the dualism of the Deceiver and the Deceived, which normally is present in lying, has been altered by the unity of a single awareness. Moreover, bad faith is an inner experience and as such it does not come from the external world like it does in Mit-sein.

As Sartre [1] points out, "one does not undergo his bad faith; one is not infected with it; it is not a state. But consciousness affects itself with bad faith. There must be an original intention and a project of bad faith; this project implies a comprehension of bad faith as such fundamentally and a pre-reflective apprehension of consciousness as affecting itself with bad faith. that is, the one we lie to and the one who lies are one and the same person, and that means that I as a deceiver am aware of the fact that is hidden from me as the deceived, and also that I must know the truth clearly in order to mask and obscure it more carefully, and this happens through a single project and the duality of lie is not present here".
This is not the same as what happens in Mit-sein, "but the Mit-sein can call forth bad faith only by presenting itself as a situation which bad faith permits surpassing" Stone [5]. That is, bad faith is an internal process and it does not come from external world into human beings minds. "One does not undergo his bad faith; one is not infected with it; it is not a state" Van den Hoven [6]. But that our awareness is affected seriously with bad faith and in order for this to happen it must be an initial and true objective and a plan of bad faith; "this project implies a comprehension of bad faith as such and a pre-reflective apprehension of consciousness, and by sticking with the safe, easy, default "choice", and by failing to recognize the multitude of other choices available to us, we place put ourselves at the mercy of the circumstances in the situations in which we often find ourselves, that is, a "being -in-itself rather than as a substitute for a being-for-itself" Van den Hoven [7]. The other way around, I think, "being-for-self" as a substitute for "being-in-self". In bad faith we act in a way as if we were not free to choose and we seek practical interests, according to which we then assume social roles and value systems that are entirely foreign to our awareness and to our responsible persona. Taking to an account dividing the human situation into facticity and transcendence, bad faith or factitious has two principal forms: "one that denies the freedom or any transcendence factor ('I can't do anything about it') and the other that ignores the factual dimension of every situation ('I can do anything by just wishing it'). The former is self-deception but the latter is common to people who lack a sense of reality in their lives" Van den Hoven [7]".

In one form he ignores the fact that he has the freedom to choose one or any other transcendence aspect, thinking I am not able to do anything about this, and the other form is ignoring the original and actual aspect of each very situation believing he cannot do anything about it, that it is impossible.

The final goal of sincerity and authenticity and the purpose of bad faith are not so different, for the sincerity, which refers to the past, does not concern us here, and if this sincerity would be possible here, as Flynn [8] says, "it is because in his fall into the past, the being is created as a being" in-itself". But the sincerity which aims at "itself" in present immanence inherent has as its goal to bring me to be "in-itself" mode form condition, what I am in not being what I am".

As Detmer [9] points out, the final purpose of bad faith is to be what I am in a way that I am not what I am. It can also be in a way that I am what I am not, meaning we pretend we are someone else in both cases and therefore not authentic. In order for the beings to be sincere one has to be and not be what we are at the same time. Sincerity is making them to move from one way of being to another mode of being, while in bad faith we are not able to withdraw from our being. 
That is, that we can't even imagine that we could retreat from it. But bad faith is not only contradicting the standards and values a person entertains, but also blocking the person from what he is. Additionally, he is trying to create himself as a being that is what he is not. As Sartre [2] points out, "In order for bad faith to be possible, sincerely it must be in bad faith for the norms and criteria of truth in bad faith are not the same in good faith. The nature of truth in bad faith is a way of thinking; we become a type of beings similar to objects; the ontological of the world of bad faith is that being is what it is not". Additionally the state of being is not what he is and "what is missing is persuasive evidence" Howells [10]. As a matter of fact people who live in bad faith inhibit themselves from being persuaded by the evidence that could help them to become more authentic and come out from bad faith and be transformed into good faith.

As McBride [11] points out "the original project of bad faith is a "non reflective, voluntary decision and one puts oneself in bad faith as easily as one goes to sleep and dreams, and when this mode of being has been realized, it is as difficult to get out of it. Bad faith is conscious aware of its structure anatomy constitution shape, and it has taken precautions by deciding come to decide that the metastable structure is the structure of being and that non-persuasion is the structure of all convictions principles".

\section{Conclusion}

I think bad faith and free choice are not completely acceptable as rules because there are some exceptions, for instance in countries where freedom is restricted and people are imprisoned because of their political views, or in psychosis when a person is not aware of his freedom to choose. But perhaps this is my own bad faith issue to think this way. The fact that we are all lost and have gone astray to some degree is true, but I am not sure if Sartre really explains how we can achieve authenticity when he says that both in bad faith and sincerity one is aiming to be in-itself and at the same time escaping from one's own being. Nevertheless, I consider Sartre's bad faith as a liberating style of living, which makes us more aware of our nothingness and insignificance and thereby we become more likely to aim for authenticity and be constantly continually aware of our habit to slip into bad faith so we can try to be in good faith, just like Van
Deurzen [12] says, "life is a never ending succession of moments that can be enjoyed and relished in spite of all difficulties" [1316].

\section{References}

1. Sartre Jeane (1997) Foucault and Historical Reason, Toward an Existentialist Theory of History. University of Chicago Press, Chicago, USA.

2. Judaken, Jonathan (2008) RACE after Sartre: Antiracism, African Existentialism, Post colonialism. Albany, State University of New York Press, New York, USA.

3. Anderson Thomas (1993) Sartre's Two Ethics: From Authenticity to Integral Humanity. Open Court, Chicago, USA.

4. Aronson Ronald (1987) Sartre's Second Critique. (2 $2^{\text {nd }}$ edn.) University of Chicago Press, Chicago. USA.

5. Stone, Robert and Elizabeth Bowman (1986) Dialectical Ethics: A First Look at Sartre's unpublished 1964 Rome Lecture Notes. University of Chicago Press, Chicago, USA, p. 13-14.

6. Van den Hoven, Jonathan (2011) Reading Sartre: On Phenomenology and Existentialism. Routledge, London.

7. Van den Hoven, Adrian, Leak, Andrew (2005) Sartre Today. A Centenary Celebration. Berghahn Books New York, USA.

8. Flynn, Thomas (1984) Sartre and Marxist Existentialism: The Test Case of Collective Responsibility, University of Chicago Press, Chicago, USA.

9. Detmer, David (1988) Freedom as a Value: A Critique of the Ethical Theory of Jean- Paul Sartre. ( $3^{\text {rd }}$ edn) Open Court Publishing Companyp, Chicago, USA.

10. Howells, Christina (1992) Cambridge Companion to Sartre. Cambridge University Press, UK.

11. McBride, William Leon (1991) Sartre's Political Theory. Indiana University Press, Bloomington, Indiana.

12. Bell, Linda (1989) Sartre's Ethics of Authenticity. University of Alabama Press, Tuscaloosa, USA.

13. De Beauvoir, Simone (1964-1965) The Force of Circumstances. Puman's sons.

14. Ronald Aronson, Adrian van den Hoven (1991) Sartre's Morality and History: A First Look at the Notes for the unpublished 1965 Cornell Lectures" in Sartre Alive. Wayne State University Press, Michigan, USA.

15. Edward N Zalta (2004) The Stanford Encyclopedia of Philosophy. Stanford University, California, USA.

16. Van Deurzen, Emmy (2005) Existential Perspectives on Human Issues. Palgrave/MacMillan, Basingstoke, England. 